\title{
II. Observations on the true origin of the gossamer
}

\section{J.M. Bechstein}

To cite this article: J.M. Bechstein (1799) II. Observations on the true origin of the gossamer, Philosophical Magazine Series 1, 4:14, 119-124, DOI: 10.1080/14786449908677043

To link to this article: http://dx.doi.org/10.1080/14786449908677043

$$
\text { 曲 Published online: } 18 \text { May } 2009 .
$$

Submit your article to this journal

LII Article views: 2

Q View related articles $\asymp$ 
fo as to be fomewhat ftretched. Through each fubftance the found was modified in a manner a little different. By refting a ftick or other body againft the temples, the forehead, and the external cartilaginous part of the ear, found is conveyed to the interior organs of hearing, as will readily appear if you hold your watch to thefe parts of another perfon who has ftopped up his ears. From this it appears, as well as from many known experiments made in regard to hearing under water, that in moft of our books on the elements of phyfics, in which in general accouftics have had the undeferved fate of being treated in a much more imperfeet manner than other parts of philofophy, found is very improperly confidered only as a vibration of the air, and the theory of it referred to the head of Air. Hearing is nothing elfe than, by means of the organs of hearing, to be fenfible of the tremulous movement of an elaftic body, whether this tremulous movement be conveyed through the air, or any other fluid or hard body, to the auricular nerves. It is alfo effentially the fame whether, as is ufually the cafe, the found be conveyed through the internal part of the ear, or whether it be communicated through any other part of the body. It certainly would be worth the trouble to make experiments to try whether it might not be poffible that deaf and dumb people, when the deficiency lies only in the external organs of the ear, the auricular nerve being perfect, could not, by the above method of conducting found, be made to hear dif tinctly words articulated as well as other founds.

II. Obfervations on the true Origin of the Golfamer, By J. M. BeCHSTEIN *.

$7 \mathrm{O}$ explain the origin of the goffamer is an old problem which, after a number of experiments, no one, as far as $\mathbf{I}$ know, has yet fully folved. Some naturalits have confidered

From Magazin fikr das Neuefe aus der Pbyfik. Vol. VI. Part I. p. 53. 
this phenomenon as the evaporation of plants condenfed during the cool days of harveft by the air, and converted into. threads like thofe which can be drawn from refinous juices; others, as the production of a kind of fpider, on account of its fimilarity to the threads of common fpiders *: and M.D.C. Pereboom has lately difcovered a kind of beetle furnithed with a veficle on its back, from the hinder part of which, on both fides, proceed two threads that extend over the extremity of the body, and end in a double thread, fometimes ten or more ells in length; and this thread is fuppofed to be what is commonly called the Goffamer.

After many years experience and obfervations made almof daily when this phenomenon appeared, I flatter myfelf that

* In the country, during autumn, certain threads are feen hanging from the trees, or extended on the buthes, and even the grafs, which, when agitated by the wind, detach themfelves from the branches, are tranfported to others, and are joined or feparated at the pleafure of the breeze. People in walking often find their faces, hair, and clothes, covered with them. They are generally called the threads of St. Martin (filets de St. Martin), becaufe it is about St. Martin's day that they appear in the greatef abundance. When the moifure of the atmofphere and the dew attach themfelves to thefe threads and become congealed, fo that the threads appear thicker and whiter, the peafants call them the hair of the Virgin Mary (cheveux de la Vierge Marie). Having one day atked them the caufe of this production, they unanimoufy replied, and without variation, that it was the sapours of the earth, which at that feafon are thicker and denfer. $I$ had ino great confideuce in this opinion : but I foon learned the real truth; for, being in a ficld overfpread with heath in the time of autumn, I obferved that almoft all the heath-buthes were covered with fpiders webs, and when thefe were opened $I$ found inclofed in each a fpider. Thefe fpiders were fmall, of a red colour, and marked wirh fpots; their feet were frort, and the head was large in proportion to the belly. Such Spiders webs are found among the low thrubs that grow near the earth, at the bottom of falks of corn which have been left ltanding by the reap. ers, and in the buthes. When the wind is trong it breaks thefe webs, carries away a part of them, which are fcattered over the ground and the zrees, and herice come the threads of St. Martin. Huetiana, Amferdam 8:23: p. 350. EDir. 
I am able to refolve the problem, refpecting its origin. In my opinion the goffamer arifes from nothing elfe than a certain kind of field-fpiders, which are, however, to fnall and active, that they almoft always efcape notice, unlefs the obferver is endowed with great acptenefs of fight. I would call this fpider, if it has already no name, the goffamer fpider (aranea obtextrix): I fhall here give a fhort defcription and hiftory of it, as far as my knowledge extends.

The goffamer fpider (aranea obtextrix) is as large as the. head of a fmall pin. On the fore-part of its longinh head it has eight grey eyes placed in a circular form; the extremity of the body is fhaped like an egg; the body itfelf is of a fhining dark-brown colour; the feet are of a moderate length, and yellowifh; and the whole animal is covered with infulated hairs.

Thefe infects frift appear in the beginning of October, in woods, gardens, and meadows, where their eggs may be hatched unhurt and unmolefted, and thence fpread themfelves over whole diftriets, fo that during all the month of October and till the middle of November they may be found on the dry fields throughout all Europe; and as they produce a numerous progeny, extenfive tracts may fometimes be feen fwarming with them. - The young, which have not attained to their full growth, are not larger than the point of a pin; they are black, with grey feet, and almoft imperceptible to the naked eye. In the beginning of October, when very few of them have been hatched, one obferves only in the funthine a few fingle threads of their webs, which they extend from twig to twig, or from ftraw to ftraw; but about the middle of the month their threads become more perceptible; and towards the end, if people ftand or place themfelves in fuch a pofition that they can fee the fun-beams playing on the tender threads, they perceive hedges, meadows; coin-fields, ftubble land, and even whole diftricts, covered with a fine white thick fort of gauze. This fpider belongs to that kind which do not weave webs, but only extend fingle 
threads from one place to another, and which Linnæus, or that account, includes in a particular divifion. The threads, owing to the fmallnefs of the animal, are fo delicate that a fingle one cannot be diftinguifhed by the naked eye unlefs when the fun fhines upon it. A thread, to be vifible at other times, mutt be compofed of at leaft fix threads twifted together; and fuch a thread, as the fingle ones are exceedingly brittle and do not readily unite, may be again eafily divided into its component threads. During the ferene calm days of the above months thefe animals carry on their occupation with great diligence, efpecially after the morning fogs have difappeared. Between the hours of twelve and two, however, is the period when their great induftry excites moft admiration. If people are poffeffed of good eye-fight, or are furnifhed with a magnifying glafs, they may find among the barley ftubble fuch a multitude of thefe fpiders employed in extending their threads, that the fields appear as if covered with fwarms of gnats, and they perform their labour fo speedily that they feem to fly from one ftubble to another.

Thefe tender threads, which are extended over whole fields, particularly in the lat half of October, become twifted together by the gentleft bresth of wind, and form perceptible threads, that, being broken loofe by a ftronger wind, are united into thick threads, and even balls, that float through the atmofphere. They are known then in Germany by the name of the flying fummer *, becaufe the fummer feems as it were to fly away at the fame time, The fpiders alfo are then conveyed along in them; and it is not uncommon to find thefe animals entwifted in fuch threads which have been caught $t$.

* In German fiegende fommer.

+ A fingular ufe which fome kinds of fpiders make of their webs is, that they ferve them infead of carriages to perform long journies, and to tramf port themfelves from one country to another. At certain times of the yeor we may generally fee, when the $\mathrm{kky}$ is ferene, a multitude of frong threads and balls formed of the threads of thefe infects, floating about in the atmo- 
All the fpiders, however, found in thefe threads or balls, mult not be confidered as the animals by which they were prepared; for other kinds of ipiders, common in harveft, are fometimes entangled in thefe threads and carricd along with them. Thus, for example, the black and white fpotted trec-fpider, and the fo called cheftnut-fpider, are often found inclofed in the goffamer together with their habitations, and muft obey the impulfe of the winds.

Thefe webs, which confift of threads clofely joined together, ferve the infects as nets, in which they catch very fmall black flics, gnats, and winged tree-lice, the juices of which they fuck for their nourifhment. The goffamer, therefore, is often found filled with the dricd liuks of fuch infects.

The above, in my opinion, is the real origin of the gorfamer. But why do thefe fpiders appear only in the time of harveft? why not earlier? and why are they not found like the houfe and field-fpiders throughout the whole fummer? -Thefe objections obviate themfelves. They appear at that period for the fame reafon that may-bugs (maykaffer) appear in the month of May. They are as neceflary in their order to preferve the equilibrium of the balance of Nature as the maybugs are in May. Single fpiders of this kind, however, may be found the whole fummer through, as fingle may-bugs are found in harveft. To thofe who know that exactly about this time thofe birds, for whofe nourifhment infects have been affigned, undertake their cmigrations, and that the larks in particular, which are fo fond of fpiders, then leave us, the above phenomenon will not appear wonderful, but will rather be confidered as a wife regulation of Nature. Thofe who wilh to be convinced of the truth of this obfervation need only to thoot a lark at that period and to open it imme-

fphere; and when thefe threads and balls are examined, they will always be found to contain fpiders, which have prepared thefe fubftances to cnable them to fly without wings, and to procure themfelres an eafy paffage to other countrics. Tobologic des Infedes par Leffer, avec des Remarques de P. Lyonsct. A la Haye, 1742. Vol. I. P. 346. Edrt. 
diately. Thefe infects, together with the grains of baricy which drop from the ears, muft indemmify thefe birds, which ftop in many places on their paffage in great numbers, for the lofs of the fummer infects.

After what has been faid, I do not think that the whitenefs of the threads, which arifes from nothing elfe than the dews that fall at that period, or their clamminefs when rubLed between the fingers, not obferved in the threads of other fpiders, and which is occafioned by the finenefs of the threads, that fo eafly infinuate themfelves into the cavites of the fkin, can be brought as any objection againft this mode of explanation. Thefe phenomena can have no weight unIefs we afcribe thefe threads to the common fpicler. It is rikewife very improbable that the goffamer is produced, as M. Percboom afferts, by his beetle; which however muft excite our admiration, becaufe, like the fpider, it weaves for itfelf a net, either to ferve it as a habitation, or as the means of catching its prey.

1II. Remarks on Mr. Sheldrake's Differtation on Painting in Oil in the Manner of the Venetians. By Mr. Evward Dares. Comnunicaled by tbe Autbor.

$\mathbf{P}$ ERSUADED that Mr. Shcldrake labours under a miftake, which may lead others into a practice difficult in itfelf and dangerous to the durability of their works, I thall offer no apology for the following remarks on his Differtation *.

That the Venetians primed with diftemper, is true; but the colour ufed was not a brown, as Aated by Mr. Sheldrake, but a $r e d$, known at prefent by the name of Venctian rad. Some artifts at this time employ the fame colour, previoully calcined, in a new Venetian method: I fay a new one, for there are two or three. One of the fecrets confifts in prime

- S.ee Plit. Mag. Vol. II. p.302. 